\title{
Comunicación, rurbanidad y desarrollo: los aportes del documental'
}

\author{
Edgardo Carniglia \\ (Universidad Nacional de Río Cuarto, Argentina)
}

Recibido: $24 / 4 / 2014$

Aprobado: 10/6/2014

\begin{abstract}
Resumen: La persistencia de la exclusión, como indicio de la crisis social estructural de las sociedades latinoamericanas, instala en la teoría de la comunicación para el desarrollo la relevante problemática del tratamiento de los géneros mediáticos sobre la pobreza, la marginalidad, la desigualdad y otros hechos sociales equivalentes. Estudios recientes sobre la cobertura mediática de los fenómenos de la rurbanidad destacan que las noticias y los periodistas de los medios de comunicación construyen un estereotipo sobre los actores, las experiencias, los objetos y los contextos del uso de carros con caballos en las ciudades. En cambio, algunos documentales sobre la híbrida condición rurbana proponen, en su diversidad, una mirada diferente posicionada desde el compromiso artístico, la intervención de la política pública y la interpretación académica.
\end{abstract}

Palabras clave: documental / carreros / rurbanidad / desarrollo

\section{Communication, rural-urban and development: the contributions of documentary}

Summary: The persistence of exclusion is an indication of structural social crisis of Latin American societies. This condition installs in communication for development the relevant issue of treatment of media about poverty, marginalization, inequality and other social events. Recent studies on the treatment of the rural-urban links by the press emphasize that journalists and the news construct stereotypes about the use of carts and horses in cities. However, some documentaries about the hybrid rural-urban condition propose another different look from the artistic compromise, the intervention of public policy and the academic understanding.

Key words: documentary / carters / rural-urban / development

1 Programa de Investigación "Comunicación y rurbanidad: formas y expresiones situadas". SECyT-UNRC (Resol. Rectoral 852/11). 
La rurbanidad, entre los medios y un género audiovisual

L a persistencia de la exclusión, y la crisis social que conlleva como fenómeno estructural de las sociedades latinoamericanas, instala en la teoría de la comunicación para el desarrollo la relevante problemática del tratamiento de los géneros o dispositivos mediáticos sobre la pobreza, la marginalidad, la desigualdad y otros hechos sociales similares y equivalentes, por ejemplo, de Argentina.

En este sentido, tres estudios recientes sobre el tratamiento mediático de los fenómenos de la rurbanidad, esa condición que mixtura lo rural y lo urbano en diversas formas situadas, destacan que las noticias y los periodistas de los medios impresos y televisivos tienden a construir un estereotipo sobre los actores, las experiencias y los contextos del uso de carros con caballos en las ciudades del interior de Argentina. Monteiro (2009) concluye que los periodistas del programa televisivo de mayor audiencia, un noticiero del único canal local de aire con hasta cuatro ediciones diarias, tienden a coincidir en una mirada de las "actividades de refugio", asociadas a la citada condición, como vida material "miserable", segregada y excluida. Estos cronistas poseen libertad para escoger el encuadre de las noticias específicas, pero convergen en un tratamiento o perspectiva llamado "social y humanitario" que, como estereotipo periodístico, conforma el pseudoambiente informativo local. Asimismo, Demarchi (2009) destaca que la construcción noticiosa del fenómeno rurbano por el único diario editado en una ciudad mediana del sur de la provincia de Córdoba es una fuente valiosa para identificar cómo es representada, pensada e imaginada la rurbanidad en el espacio regional: en su uso de temas, clasificaciones y fuentes. Las noticias de la prensa local presentan a los sujetos rurbanos como, al mismo tiempo, agentes y pacientes de diversos problemas citadinos. Finalmente, Capiello (2009) explora estos mismos tratamientos en diarios digitales de ciudades intermedias de la pampa y otras regiones argentinas.

Por otra parte, trece documentales de los últimos lustros tratan sobre las prácticas, las vidas y los mundos de los sujetos que sobreviven en la ciudad argentina del siglo XXI como recolectores informales de residuos; algunos de esos materiales de video y cine, en particular cuatro textos, abordan las experiencias de los cirujas y otros agentes que, bajo distintas denominaciones, emplean carros tirados por caballos en la recolección de basura y otras actividades.

En consecuencia, interesa conocer cuál es el tratamiento de estos documentales recientes sobre los actores, las experiencias y los contextos de la utilización de carros tirados por caballos en las ciudades del interior de Argentina. 


\section{Carros y caballos en la ciudad del siglo XXI}

En condiciones de modernidad avanzada periférica, la ciudad nunca es única ni tampoco deja de constituirse desde una historia específica y por sus relaciones con otros espacios urbanos y/o rurales.

La utilización de carros tirados por caballos en las ciudades, ya sean las capitales o las urbes del interior de Argentina (Kenbel, 2006; Cimadevilla y Carniglia, 2009) y otras naciones latinoamericanas (Schamber y Suárez, 2007), integra las estrategias de vida de los hogares en condiciones de exclusión cuyos miembros realizan, entre otras actividades, tareas de recolección de residuos dentro del llamado circuito informal de la basura. En varias urbes latinoamericanas - Buenos Aires, São Paulo, Bogotá y Montevideo-, así como en ciudades del interior argentino - Río Cuarto, Tucumán y Bariloche-, la recolección de materiales reciclables (papel, metal, vidrio, plástico y escombros, entre otros) de la vía pública y su retirada de comercios, oficinas y viviendas constituye una fundamental fuente de ingreso para numerosos hogares empobrecidos que, en muchos casos, ingresan a la actividad luego de una prolongada e inútil búsqueda de empleo (Schamber y Suárez, 2007).

Históricamente, existieron en las ciudades argentinas actores que hacían de los residuos urbanos un recurso o medio de vida. Las antiguas y po- pulares expresiones ciruja, botellero y linyera, entre otras, reconocen a dichos sujetos (Baigorria, 1998; Schamber, 2008). Los recuperadores de residuos tienen, como dicen Schamber y Suárez (2007, p. 26), "un origen centenario atravesado por las vicisitudes de una sociedad que no termina de definir qué hacer con la basura, ni qué status darle a quienes la ingresan al circuito productivo desde los márgenes y en pésimas condiciones laborales".

Sin embargo, con las crisis socioeconómicas, en particular del último cuarto del siglo $X X$, emergieron en Argentina otros actores individuales y colectivos que expandieron dichas prácticas desplazándose entre los tres circuitos del tratamiento de los residuos urbanos: i) los rellenos sanitarios municipales, ii) las calles y edificios de la ciudad, y iii) los basurales a cielo abierto de la ciudad y el campo (Shammah, 2009). Así, hacia mediados de los años noventa, junto a la manifestación de los signos críticos de la desocupación, paulatinamente reaparecieron los recolectores informales de materiales reciclables en Buenos Aires y diversas localidades del interior. Hacia el año 2000, la actividad de recuperación informal de basura en la vía pública comenzó a ser mucho más notable en las calles de la capital y otras ciudades argentinas (Kenbel, 2006; Schamber y Suárez, 2007).

Una parte de los recuperadores de residuos desarrollan sus experiencias en ciudades argentinas y también en 
otras urbes latinoamericanas, mediante el empleo de carros tirados por caballos que despliegan, además, en otras tareas diversas: transporte de carga, movilidad del grupo doméstico, venta callejera y actividades recreativas, entre otras. Por ejemplo, en Río Cuarto (Argentina), una ciudad de aproximadamente 165000 habitantes y ubicada al sur de la provincia mediterránea de Córdoba, las estimaciones oficiales indican que, en la primera década del siglo XXI, alrededor de 400 hogares utilizaron unos 2000 caballos, un objeto netamente rural, en dichas actividades.

Desde una perspectiva de la comunicación para el desarrollo se considera como rurbanos - o sea, una mixtura entre lo rural y lo urbano- a los actores, las experiencias, los objetos y los contextos de la utilización de carros tirados por caballos en ciudades de la pampa argentina (Cimadevilla \& Carniglia, 2009).

Ampliando esta perspectiva, se sostiene aquí, bajo la orientación teórica de Raymond Williams (2001), que bajo condiciones de capitalismo, en particular periférico, las relaciones entre el campo y la ciudad -o entre lo rural y lo urbano- se muestran diversas, intensas y cambiantes. Es decir: las tramas que ligan a lo rural y lo urbano remiten a numerosas situaciones o fenómenos con significativas implicancias materiales y simbólicas y sujetos a dinámicas de cambio. Esta conjetura supone, además, que la ma- nifestación de las complejas interpenetraciones entre el campo y la ciudad puede alcanzar incluso a fenómenos específicos fundados en cierta configuración e historicidad particulares de las sociedades con el capitalismo aquí denominado como periférico.

De este modo, en un sector occidental de la región social agraria argentina conocida como pampa, se observan diferentes modalidades de articulación entre el campo y la ciudad:

a) Una de las manifestaciones, acaso relativamente dominante en la configuración sociocultural de la pampa argentina, radica en la conformación diversa de agrociudades como espacios híbridos, en tanto algunas urbes medianas, por ejemplo, la mencionada Río Cuarto, funcionan como núcleos de comercio y servicios de una región con una economía predominantemente agropecuaria.

b) Otra de las expresiones de la articulación campo-ciudad, en este caso, emergente pero muy visible, remite a la presencia y actuación en dichas ciudades de distintos actores mixtos, esto es, "rurbanos" o "rururbanos", como los recicladores de residuos que, con una particular ecología de objetos (Galimberti, 2008), utilizan carros impulsados por caballos.

c) Un conjunto de prácticas socioculturales, entre residuales y emergentes como la vida en los núcleos residenciales cerrados llamados 
countries, hablan de otros sentidos de una interrelación que, como se dijo, asume una densidad tematizadora de la importancia que los vínculos entre lo rural y lo urbano implican para la vida cotidiana en la ciudad cabecera de dicha región, o sea, Río Cuarto, y el conjunto regional.

d) Algunas experiencias situadas de consumo cultural suponen la interacción entre los textos de los medios de comunicación y los actores rurbanos, por ejemplo, la lectura de la prensa agraria mercantil por productores agropecuarios devenidos ahora en residentes urbanos (Carniglia, 2012).

\section{Narrar la ruralidad con imágenes y sonidos}

En este sentido, ¿se narra actualmente lo rural, y en particular la cuestión rurbana, en los formatos audiovisuales argentinos? En la respuesta al interrogante cabe distinguir entre, por un lado, el pasado y el presente del panorama audiovisual y, por otro, los distintos formatos, en especial el cine y el (video) documental.

El complejo estudio de Lusnich (2007) recorre un extenso período de la historia del cine argentino para identificar un modelo o tendencia de los filmes de ficción asociado a la manifestación del clivaje rural/urbano en la filmografía nacional. La autora es- tablece tres ciclos o fases de la historia del cine argentino: el filme silente, 1896-1932; los años dorados o período clásico, 1933-1956; la irrupción de la modernidad y el cine de autor, desde 1957 a la actualidad. A la segunda etapa corresponde el drama socialfolclórico, analizado por aquella como específico de las ruralidades y contemporáneo del otro modelo espectacular argentino predominante en este período cinematográfico: el drama social urbano.

En consecuencia, el objetivo fundamental de la investigación de Lusnich (2007) consiste en el análisis de las reglas de competencia textual y de las pautas cinematográficas que rigieron la producción y circulación del drama social-folclórico, uno de los modelos de representación hegemónicos en el período de emergencia y desarrollo de la industria cinematográfica argentina. Su método analítico comprende tres ejes: la película como texto, o experiencia estética singular e irrepetible, en la que se produce una determinada lectura y producción de sentido; la película como polifonía, es decir, vinculada con textos cinematográficos próximos, otras series artísticas y contextos de producción y circulación; y la película como sistema, o sea, un orden que regula las conexiones entre los filmes y pone en evidencia la circulación de una determinada ideología de representación. Desde dichas categorías estudia la estructura narrativa, el sistema de personajes, el tratamiento figurativo, la estructura 
enunciativa y el nivel semántico de un corpus de sesenta películas y material complementario. El corpus analizado incluye textos de los dos modos, ambos con variantes internas del drama cinematográfico social-folclórico: i) el filme biográfico de héroes históricos o populares, y ii) la película de ambientación histórica sobre las luchas por la conformación de la nación, los conflictos socioeconómicos y las intrigas románticas y sentimentales.

Lusnich (2007) destaca, entre sus conclusiones, lo siguiente:

Los filmes que integran el modelo del drama social-folclórico conforman un corpus fílmico homogéneo que posee una estructura relativamente estable, sustentada en cinco rasgos definitorios: a) el diseño de una estructura narrativa y dramática transparente, que implica el desarrollo y el cumplimiento de un trayecto espacial y temporal conformado por diferentes momentos internos (exposición, desarrollo, desenlace y clausura); b) la formulación de un sistema de personajes basado en la interacción de dos categorías básicas: el protagonista y el entorno social; c) la tendencia a un estilo visual/sonoro que intensifica la presencia de un conjunto de elementos significantes que cumplen funciones narrativas y dramáticas precisas; d) una estructura narrativa que incluye la construcción de relatos enmarcados y la homogeneización de las distintas instancias narrativas; y e) el registro y el desarrollo de las dicotomías civilización/ barbarie y campo/ciudad en el nivel semántico de los textos fílmicos (p. 24).
Por otra parte, las secciones y los suplementos de artes y espectáculos de los diarios argentinos muestran, en la primera década del siglo XXI, que mientras se discute en el país la emergencia y evolución de un "nuevo cine argentino", o sea, otra etapa de la historia fílmica, muy pocas o ninguna de las aproximadamente cuarenta y cinco películas nacionales estrenadas cada año se abocan a la problemática rural y/o contemplan la relación entre los campos y las ciudades de esta nación sudamericana. Así, por ejemplo, en el año 2008, inusualmente tres filmes incorporan con cierta relevancia algunas problemáticas actuales del campo. En Rancho aparte (E. Flehner, 2007) comienzan a aparecer los problemas cuando dos campesinos se mudan a la elegante vivienda de un pariente en Buenos Aires luego de vender, forzosamente, su rancho. Asimismo, La rabia (A. Carri, 2008) muestra, también, conflictos familiares, pero ahora en el campo. Finalmente, una maestra rural y un conductor de transporte público inician un romance tras una serie de confusiones en torno a $\mathrm{El}$ frasco (A. Lecchi, 2008), que contiene una muestra de orina.

Sin embargo, una mayor visibilidad de la condición rurbana contemporánea se detecta en varias piezas u obras de otro formato audiovisual específico: la narración a través del documental $y$, en una era de opulencia tecnológica y cultura de las imágenes, el videodocumental. 
Nuestra recopilación ha identificado trece películas, en general, videodocumentales de distintos realizadores argentinos y extranjeros que presentan su propia versión sobre, entre otros, los actores, las experiencias y los escenarios de la recolección informal de residuos y la rurbanidad, a saber:

- Dársena Sur (P. Reyero, 1997, Argentina)

- Cartoneros de Villa Itatí (A. Cacopardo et al., 2003, Argentina)

- Días de cartón (V. Souto, 2003, Argentina-España)

- El tren blanco (N. García, 2003, Argentina)

- Caballos en la ciudad (A. Gershenson, 2004, Argentina)

- Construyendo dignidad (Grupo UCRUS, 2005, Uruguay)

- Los cartoneros (M. McLean, 2006, Estados Unidos)

- Monedas de cartón (El Cuarto Patio, 2005, Argentina)

- Cidades e soluções (GloboNews, 2007, Brasil)

- Ciudad oculta (Municipalidad de Río Cuarto, 2007, Argentina)

- Rurbanos (L. González \& M. Segretín, 2007, Argentina)

- Carreros (L. González, 2009, Argentina)

- Yatasto (H. Paralluelo, 2011, Argentina)

\section{El documental: historia, estilo y modos de representación}

Como se dijo, desde el punto de vista analítico, interesa el documental en tanto texto, polifonía y sistema que constituye un relato o modo de representación sobre diferentes realidades sociales e históricas (Nichols, 1997; Barnouw, 2005), por ejemplo, las asociadas a la rurbanidad en América Latina.

El origen y la trayectoria del documental, un género que atraviesa su segundo siglo de vida, se ligan estrechamente a la evolución del primer medio audiovisual, o sea, el cine, que constituyó su matriz; a las tendencias de las tecnologías de la información y la comunicación; a la dinámica de los medios de comunicación, y a los usos sociales del género a lo largo de diferentes coyunturas. Todas estas fuerzas de la producción, la distribución y el consumo culturales generaron un rico campo de estilos y modos de representación que hoy sobreviven como alternativas no necesariamente excluyentes para los documentalistas y sus públicos.

En este sentido, Barnouw (2005) identifica las siguientes seis etapas en la historia del documental:

a) Emerge en el último cuarto del siglo XIX desde la preocupación de, entre otros, algunos científicos por documentar determinado fenómeno o acción con la película inventada por los hermanos Lumière, y 
este primer período pronostica las diversas e interrelacionadas funciones potenciales del realizador de filmes documentales y sus obras.

b) Entre 1910 y 1929, los documentalistas, como por ejemplo, Robert Flaherty a través de Nanook, el esquimal, hicieron de exploradores filmando pueblos primitivos; ellos se convirtieron en reporteros de los cambios sociales, como Dziga Vértov en Rusia, y otros artistas fueron pintores, que se apropiaron de los elementos del cine que afectó a todas las artes plásticas. Unos y otros experimentaron con las imágenes en movimiento desde un espíritu complaciente y optimista y sus películas rara vez eran polémicas.

c) La transición hacia la etapa siguiente coincidió con dos transformaciones: el advenimiento del cine sonoro y la depresión mundial. Ambas transiciones se relacionaban, pues el paso al cine sonoro se inicia como una desesperada apuesta de los productores que enfrentaban la ruina económica, y determinaron profundos cambios en la película documental. De la mano de John Grierson y otros en todo el mundo, la película muda, con el agregado de la narración de una voz en off, se tornó en un abogado, al dramatizar políticamente situaciones conflictivas y sus implicaciones para guiar al ciudadano a través de la espesura de la democracia y los procesos sociales impersonales; en un toque de clarín, que pretendía encender las pasiones nacionalistas e incitar la determinación guerrera al máximo nivel, al tiempo que procuraba paralizar al enemigo; y en un fiscal acusador, con Andrew y Annelie Thorndike que utilizaban el material de archivo para documentar sus acusaciones sobre los crímenes y las atrocidades de la guerra. Los autores de estas películas se manejaban cerca de los centros de poder y su público creció en las salas cinematográficas y otros escenarios: cuarteles, clubes, escuelas, iglesias, bibliotecas, oficinas y fábricas. La difusión global de los proyectores de dieciséis milímetros consolidó este formato de película.

d) Tras las batallas de la Segunda Guerra Mundial surgieron varias tendencias del documental. Una perspectiva se orientaba hacia un texto híbrido, la película de ficción con visos de documental. Otra corriente hizo del documentalista un poeta, como Arne Sucksdorff, que contemplaba maravillado el mundo circundante posterior a los años de la matanza; un cronista histórico, por ejemplo, a través de varios formatos (informe de antropólogos, documentos de la vida salvaje y exploración del cuerpo humano), que utilizaban como materia prima los valiosos noticiarios acumulados durante medio siglo y contaban con un importante apoyo de la televisión emergente; y un promotor, 
acicateado por los recursos de la industria, en especial de las compañías multinacionales, interesadas en promover un producto, las ventas, las instituciones y las opiniones favorables. En este último caso, dada la purga ideológica y política de la época, se trataba de audiovisuales domesticados que reflejaban la evolución de una televisión mercantil, en expansión a otros países.

e) Desde fines de la década de 1950, la historia del documental registró el nacimiento de varios géneros de disentimiento. Los documentalistas hallaron oportunidades en los nuevos equipos técnicos que facilitaban las tomas móviles y la sincronización del sonido, crecientemente importantes en la década siguiente y en los nuevos sistemas de distribución, por caso, la televisión pública. Así, los realizadores se convierten en un observador, cuyas películas de "cine directo" con acento en las personas que hablaban eran ambiguas, porque a menudo las conclusiones quedaban libradas a los espectadores; o en un agente catalizador, que reconocía el impacto que la cámara tenía en los hechos filmados, pero, en lugar de considerarlo un factor negativo, lo estimaba, como hacía Jean Rouch con su cinéma vérité, un sujeto revelador de la verdad interior y oculta, que las circunstancias artificiales hacen emerger a la superficie. Sin embargo, en una época de crecientes tensiones otros documentalistas se manifestaban como abiertamente críticos ante las crisis mundiales, y en todos los continentes surgieron los documentales del realizador guerrillero que contribuyeron a ampliar el pensamiento social. En la década de 1970, la actividad documental se amplió con el nacimiento de los equipos de video (cámaras compactas y consola de edición) y los nuevos sistemas de distribución (cable, canal público y satélites).

f) En el segundo siglo del documental, los realizadores se multiplican $\mathrm{y}$ convierten en un movimiento internacional fertilizado por el empleo de la comunicación por satélite, la computadora con sus redes digitales y el propio videorreproductor. Las varias posturas alternativas del documentalista no se excluyen y cada documentalista casi siempre combina dos o más de los personajes identificados. La intervención de mujeres se destaca ahora como no había acontecido previamente, y el movimiento también se multiplica con la actividad de grupos interesados en la guerra, los problemas ambientales, la pobreza, la corrupción y el poder de los medios de comunicación.

Como historiador, Barnouw (2005) omite una discusión teórica sobre el documental como un género que destaca y analiza en su evolución histórica. Su conceptualización apenas indica al respecto que los documentalistas: 
[...] sienten pasión por lo que encuentran en las imágenes y en los sonidos, que siempre les parece más significativo que todo cuanto puedan inventar. Esos documentalistas pueden servir como agentes catalizadores; no son inventores. A diferencia del artista de ficción, no están empeñados en inventar. Se expresan seleccionando y ordenando sus hallazgos y esas decisiones constituyen en efecto sus principales comentarios. Y lo cierto es que no pueden escapar a su propia subjetividad individual, ya adopten la posición del observador, ya adopten la del cronista o la del pintor. Los documentalistas presentan su propia versión del mundo (p. 313).

En este sentido, agrega el autor, que las múltiples elecciones expresivas del punto de vista consciente y/o inconsciente del realizador incluyen los temas, las personas, las vistas, los ángulos, las lentes, las yuxtaposiciones, los sonidos y las palabras, entre otras condiciones.

Las modalidades de representación contenidas, al menos implícitamente, en la historia del documental, trazada desde dicha mirada historiográfica, son recuperadas y discutidas en la obra más conceptual de Nichols (1997). A él le interesa otorgar a la cinematografía documental, desde la teoría intercultural, el valor de una forma o género audiovisual distinto de los largometrajes de ficción y, por ende, con problemas y placeres propios.

Para este autor, el cine documental tiene cierto parentesco con otros siste- mas de no ficción que llama los discursos de sobriedad: ciencia, economía, política, asuntos exteriores, educación, religión y bienestar social. que son dispositivos que dan por sentado su poder instrumental. Según Nichols, los discursos de sobriedad

pueden y deben alterar el propio mundo, pueden ejercer acciones y acarrear consecuencias [...] tienen un efecto moderador porque consideran su relación con lo real directa, inmediata, transparente [...] son vehículos de dominio y conciencia, poder y conocimiento, deseo y voluntad (1997, p. 32).

Sin embargo, la capacidad de la articulación entre las imágenes fotográficas y el sonido grabado para habilitar registros de la realidad no ha elevado el documental al rango de los otros discursos de sobriedad. Con todo, el documental, como otros discursos sobre lo real histórico, conserva una responsabilidad residual en la descripción e interpretación del mundo de la experiencia colectiva y, más precisamente, se conjuga con dichos discursos en una construcción auténtica de una realidad social.

Nichols (1997) discute la habitual definición del documental como un ejercicio en el que los realizadores tienen un menor control sobre sus temas, en comparación con sus homólogos de la ficción audiovisual. Entonces, considera al documental desde una perspectiva tridimensional que integra al realizador, los textos y los espectadores. 
En primer lugar, la realización documental consiste en la práctica de una comunidad de discurso institucionalizada. En esta la preocupación fundamental por la representación del mundo histórico hace surgir y enfrentarse diversos principios organizativos, patrones de distribución y exhibición, estilos, estructuras, técnicas y modalidades. Luego, el documental como texto corresponde a un género o sistema, cuyas películas comparten diversas normas, códigos y convenciones, a saber: a) una estructura paradigmática que funciona en términos de resolución de problemas, la invocación de una lógica informativa o documental; b) la dependencia de los sonidos e imágenes como pruebas, el montaje probatorio y la construcción de un argumento; c) la primacía de la banda sonora, el comentario, los testimonios $\mathrm{y}$ las narraciones en concreto; y d) la naturaleza y funciones históricas de los diferentes modos de producción documental. Finalmente, los espectadores desarrollan capacidades de comprensión e interpretación del documental, que constituyen una forma de conocimiento metódico, derivado de un proceso activo de deducción basado en la experiencia anterior y en el reconocimiento del propio texto. Una de las expectativas fundamentales del documental expresa que los sonidos e imágenes tienen una relación indicativa con el mundo histórico.

Como se dijo, Nichols identifica modalidades de representación de di- cho mundo que son patrones organizativos dominantes o "formas básicas de organizar textos en relación con ciertos rasgos o convenciones recurrentes" (1997, p. 65). Destaca cuatro concepciones del documental, potencialmente disponibles desde los inicios de la historia del cine: i) expositiva, ii) de observación, iii) interactiva, y iv) reflexiva. Cada alternativa predominó en regiones o países determinados, pero las modalidades también tienden a alterarse y combinarse dentro de películas determinadas. Las modalidades representan diferentes conceptos de la representación histórica y emergen desde el desafío y el enfrentamiento con una alternativa previa. Así, siempre la emergencia de una modalidad aporta nuevas variaciones para la estructura y el contenido del documental.

El documental expositivo (Flaherty y Grierson, entre otros) surgió del desencanto con las molestas cualidades de divertimento del cine de ficción. Su texto se dirige al espectador, con intertítulos o voces que presentan una argumentación sobre el mundo histórico. Las imágenes sirven como ilustración o contrapunto. En un texto al servicio de la persuasión, este modo expositivo enfatiza la impresión de objetividad y de juicio bien establecido. La exposición puede incorporar entrevistas, pero estas se subordinan a una argumentación ofrecida por la propia película. El espectador del documental expositivo alberga la expectativa de que se desplegará ante él un 
mundo racional, con una conexión lógica de causa-efecto entre las secuencias y los sucesos.

La modalidad de observación (Leacock-Pennebaker y Wiseman, entre otros) se inicia como el "cine directo" de Barnouw, con los equipos de grabación sincrónicos, más fáciles de transportar y el desencanto con la condición moralizadora del documental expositivo. Hace hincapié en la ausencia de intervención del realizador y en una observación empática, acrítica y participativa. En lugar de la solución de un enigma o problema, las películas de observación toman forma paradigmática en la descripción exhaustiva de lo cotidiano. Los sonidos y las imágenes se registran en el momento de la filmación para el documental de observación. Esto facilita en este filme la captación de la experiencia contemporánea de la familia, la comunidad o una institución. Así, la modalidad de observación ha sido utilizada, a menudo, como herramienta etnográfica. $\mathrm{Su}$ espectador experimenta el texto como una reproducción de la vida, tal y como se vive.

El documental interactivo (Rouch, De Antonio y Connie Field, entre otros) emergió de la disponibilidad de dicho equipo de sonido sincrónico y del deseo de habilitar una perspectiva más explícita y evidente del realizador. Enfatiza tanto las imágenes de testimonio o intercambio verbal cuanto aquellas de demostración. El monta- je funciona para mantener una continuidad lógica entre los puntos de vista individuales. La interacción a menudo asume las formas de la entrevista y la historia oral. El texto interactivo adopta muchas formas, pero todas ellas llevan hacia el encuentro directo entre el realizador y los actores sociales. Según Nichols, el espectador del texto interactivo espera ser

testigo del mundo histórico a través de la representación de una persona que habita en él y que hace de ese proceso de habitación una dimensión característica del texto (1997, p. 92).

El documental reflexivo (Vértov, Godmilow y Ruiz, entre otros) surgió para que las convenciones de la representación audiovisual fueran más evidentes, y como una puesta a prueba o interpelación de la impresión de realidad que las otras tres modalidades transmitían normalmente. A diferencia de los otros modos documentales, este formato aborda la cuestión de cómo hablamos acerca del mundo histórico. El texto enfatiza el encuentro entre un realizador y un sujeto. En su forma paradigmática lleva a una conciencia intensificada de la relación entre el espectador y el film, así como del problemático vínculo entre el texto y aquello que representa o designa. El espectador llega a esperar lo inesperado en la propia situación de visionado o recepción del texto audiovisual. Esta reflexividad del documental puede ser tanto formal como política. 


\section{Tres relatos alternativos sobre los carreros urbanos}

Entre los trece documentales identificados sobre la recolección informal de residuos, se seleccionó para el análisis un corpus compuesto por aquellos productos audiovisuales que prestan mayor atención y detalle al uso de caballos en dicha actividad. En consecuencia, se analizaron los siguientes textos audiovisuales:

- Caballos en la ciudad (A. Gershenson, 2004, Argentina)

- Ciudad oculta (Municipalidad de Río Cuarto, 2007, Argentina)

- Rurbanos (L. González y M. Segretín, 2007, Argentina)

Como se dijo, el análisis exploratorio de cada uno de estos registros audiovisuales procuró especificar qué modo de representación caracteriza a cada documental sobre los carreros urbanos. Esto es, interesó identificar en cada documental:

- La estructura narrativa (la historia contada en cada texto)

- El sistema de personajes (el conjunto de sujetos entramados)

- El tratamiento figurativo (los recursos visuales y sonoros utilizados)

- La estructura enunciativa (la organización de cada relato)

- El nivel semántico (las categorías temáticas y las posiciones asociadas)

\section{Un recorrido urbano cotidiano con carros y caballos}

El programa narrativo de Caballos en la ciudad propone un recorrido cotidiano desde la residencia de los cartoneros o cirujas, un sector empobrecido de la provincia de Buenos Aires, hasta la ciudad capital de Argentina, cuyos barrios aquellos atraviesan de día y también de noche en busca de basura apta para consumir, reciclar y vender. Los separadores, entre los seis segmentos textuales del largometraje que relatan las prácticas de distintos recolectores de residuos, son un mapa del territorio y una secuencia de imágenes móviles sobre la represión, a cargo de policías armados con palos y escopetas para gases lacrimógenos, de los carreros que ingresan a la Capital Federal desde el conurbano bonaerense. En dicho recorrido se muestran algunos lugares de la villa como morada cartonera, las calles urbanas del trabajo diario y los mercados donde los cartoneros intercambian la basura recolectada, entre otros espacios de su práctica cotidiana.

Sobre esta trama de espacio y tiempo contemporáneo a la crisis social de la posconvertibilidad argentina, se despliega un relato cuyos personajes centrales son un conjunto de cartoneros de distintas edades y géneros. Estos, a veces, circulan en solitario por la ciudad, pero en general recorren sus calles en pareja o grupo de familiares. Así, padres e hijos participan en la recolección informal de residuos. Por otra parte, algunos personajes secun- 
darios emergen en la interacción con estos varones, mujeres, niños y adolescentes dedicados al cirujeo: los vecinos que proveen a aquellos la basura apta para reciclar, los compradores del material recolectado $y$, finalmente, los policías y otros agentes estatales encargados del control de la actividad. También los caballos, en especial las yeguas, y los carros son incorporados como cuasipersonajes de este relato sobre cómo hacer de la basura un medio de vida. En ocasiones, la cámara se detiene para mostrar cómo son alimentados, tusados y curados estos equinos, considerados por los carreros como un recurso equivalente al del "auto del rico".

Entre los procedimientos del estilo visual y sonoro se destacan las ricas y dinámicas imágenes en color que retratan a los actores, las prácticas y los escenarios de la recolección de residuos. Esas imágenes son acompañadas por el sonido sincrónico y, en algunas ocasiones, la música se instala como correlato de las tomas sobre el recorrido cotidiano de los carreros. Por otra parte, la voz en off de los cirujas, utilizada frecuentemente, constituye un recurso clave para presentar, según se analiza más adelante, la perspectiva de estos actores sobre los distintos aspectos de su trabajo cotidiano.

La estructura enunciativa interpela al público desde, como se dijo, dos relatos articulados. Uno, el más extenso, construye una mirada sobre las diferentes prácticas cotidianas de los car- toneros que diariamente transitan entre la capital argentina y la provincia vecina en busca del sustento diario. Otro, más breve e instalado como separador entre los segmentos de aquel, muestra instantes secuenciados de la violenta represión policial de la que son objeto los carreros para impedir su ingreso a la ciudad. La secuencia de este relato concluye con un zócalo que connota el fin de esta modalidad represiva, pues anuncia la autorización para el ingreso de los cartoneros a la capital durante los fines de semana.

La voz en off de los carreros representa un recurso clave para desplegar las categorías semánticas que dicen acerca de la comprensión de los recolectores informales de residuos sobre su mundo. Así, las expresiones de estos actores rurbanos:

- Destacan la pobreza como origen situacional de sus prácticas.

- Otorgan y reclaman para el cirujeo la condición de trabajo digno.

- Definen la basura recolectada como comida de todos los días.

- Asumen que en su actividad laboral comparten algunos códigos, pero también problemas como los robos de mercaderías, carros y animales.

- Reconocen el valor de sus caballos destacando el esfuerzo de las yeguas.

- Conciben la educación de los hijos como promesa de un futuro distinto del de sus padres cartoneros. 
En consecuencia, todos estos rasgos encuadran al documental Caballos en la ciudad, exhibido en su momento en algunas salas cinematográficas del circuito comercial, dentro del antes denominado modo de representación por observación. La mirada de su directora propone, principalmente, una comprensión empática del cartonero, sus prácticas y su mundo.

\section{Arriba del carro en la ciudad pampeana}

Elaborado como trabajo final de una licenciatura en ciencias de la comunicación (González \& Segretín, 2007), el videodocumental Rurbanos propone una narración sobre las experiencias de los carreros de la ciudad de Río Cuarto (Córdoba, Argentina), un conglomerado de alrededor de 165000 habitantes y centro de comercio y servicios de una región con predominio de economía agropecuaria.

La estructura narrativa se sitúa en el año 2004, para dar cuenta de la variedad de dichas experiencias. Apelando a placas fijas, se introduce al comienzo una definición de dicha ciudad como un territorio de las prácticas rurbanas, o sea, aquellas que articulan elementos rurales y urbanos. Los primeros comprenden al carro impulsado por caballos y los segundos remiten a la ciudad, con sus actividades y sus gentes. El desarrollo del documental luego presenta tres entrevistas a otros tantos carreros y carreras, para finali- zar con imágenes del trabajo nocturno de recolección de residuos en el casco céntrico de aquella urbe mediana.

Los carreros, como personajes, son presentados en la unidad y diversidad de sus experiencias. Todos utilizan dichos carros tirados por caballos para atravesar el territorio urbano en horarios diurnos y nocturnos, para realizar sus distintas actividades cotidianas. Algunos carreros, como Milo, extraen áridos del río que atraviesa y divide la ciudad; y otras recuperadoras urbanas, como María y Lorena, se dedican a la recolección informal de residuos. De este modo, en total se presentan tres personajes individuales y colectivos, pues, a veces, los carreros aparecen acompañados de uno o más hijos $\mathrm{u}$ otros familiares.

La organización visual y sonora de este documental se asienta, entre otros, en dos procedimientos reiterados sistemáticamente a lo largo de los aproximadamente cuarenta minutos de duración. Por un lado, las imágenes captadas cámara en mano, desde arriba del vehículo en movimiento, proponen dicho recorrido por las calles, dando unidad al relato y separando cada uno de sus segmentos identificados también con placas fijas. Por otra parte, un conjunto de entrevistas con tomas, en general, de plano medio y sonido directo recoge testimonios de tres familias de carreros o, como titula el documental, "rurbanos". En este sentido, al menos tres placas fijas explican el alcance de este neologismo 
que interpela a la clásica dicotomía rural/urbano de la teoría social: sus textos dicen sobre la ciudad, sobre las personas que utilizan carros con caballos y sobre estos particulares vehículos que recorren, como se dijo, las ciudades de la pampa argentina.

Las categorías semánticas propuestas por las imágenes y palabras del texto se asocian a varios aspectos de la rutina cotidiana de los carreros. Los testimonios de estos dan cuenta de una práctica que, en los términos de Lorena, una estudiante de secundaria que cirujea con su madre, "no es linda pero tampoco es fea", pues amalgama:

- La dureza del trabajo a la intemperie

- La posibilidad de subsistencia con las actividades rurbanas

- El aprendizaje de las tareas a través del grupo familiar

- La vida en una ribera del río casi sin urbanizar

- El complejo trabajo con los caballos

- Los detalles de la recolección de residuos y otros oficios

- La relación con los llamados "clientes"

- Las eventuales disputas con los vecinos

- La rutina del mate

En consecuencia, esta realización de dos estudiantes avanzadas de Ciencias de la Comunicación cabalga entre un modo de representación expositivo y otro de observación. Su texto se di- rige al espectador directamente, con intertítulos y voces que presentan una argumentación sobre el mundo histórico, en este caso, acerca de la condición rurbana. Las imágenes sirven como ilustración o contrapunto. A su vez, el documental Rurbanos enfatiza la no intervención del realizador y una observación empática, acrítica y participativa para describir exhaustivamente lo cotidiano. Los sonidos se registraron en el momento de la filmación, facilitando en este filme la captación de la experiencia contemporánea de los actores y sus familias.

\section{Los carreros de una indeseable ciudad oculta}

El documental de corta duración Río Cuarto, ciudad oculta, elaborado por la municipalidad de dicho conglomerado urbano, se propone sensibilizar a los ciudadanos locales sobre la emergencia de problemáticas sociales configuradoras de dos ciudades en dicha urbe; una visible, como dinámica y próspera; y otra oculta por vulnerable y estática, que "son parte de una misma". La pertinencia al corpus de audiovisuales sobre los carreros urbanos se establece porque el texto asocia e ilustra, generalmente, los problemas sociales de la ciudad oculta con la presencia de los cirujas y los carreros urbanos, objeto, en dicha ciudad pampeana, de algunas políticas específicas (Carlosena, 2010).

La narrativa propuesta apunta al cambio social, porque los múltiples 
problemas de la "ciudad oculta" constituyen, siempre según la voz en off, "una herida o llaga abierta" que corresponde cambiar. A veces, el programa narrativo interpela o discute, quizás por desconocimiento, a algunos enfoques contemporáneos del desarrollo, por ejemplo, sobre la sustentabilidad ambiental, cuando afirma que "la basura ajena nunca puede ser un destino". Entre los múltiples problemas del desarrollo local, reconocidos por este relato, se destacan el cirujeo, el trabajo infantil, las adicciones, los robos, la deserción escolar y el desempleo.

El sistema de personajes se sostiene en un doble despliegue de actores. La ciudadanía local en su conjunto es interpelada con el fin de sensibilizarla desde un discurso sobre el cambio social necesario. Por otro lado, se presentan los testimonios de cinco integrantes de esa ciudad oculta que hablan, de frente o de espalda a la cámara, sobre sus condiciones de vida en aspectos tales como el trabajo, la educación y el consumo de drogas, entre otros. Tres de dichos citadinos corresponden directamente al mundo del cirujeo o la recolección informal de residuos.

El tratamiento de las imágenes y los sonidos se corresponde con este entramado de personajes. De un lado, se establece un contrapunto entre las imágenes de la ciudad próspera — con sus calles, edificios, comercios y servicios poblados de gente- y la "ciudad oculta", a menudo ilustrada con planos generales de los carreros en el tránsito urbano y de los cirujas en los basurales. La voz en off enfatiza este contrapunto, tanto como el conjunto discursivo de dos placas textuales que abren y cierran este documental del municipio. Por otra parte, los testimonios, con imágenes en primer plano, de los habitantes de la "ciudad oculta" expresan las duras contingencias de su existencia cotidiana.

De este modo, se instala una semántica de cambio social en este discurso audiovisual de la municipalidad local. Los temas y las posiciones al respecto convocan, acaso desde lo políticamente correcto, a construir una única ciudad liberada de los problemas de la urbe oculta.

En este sentido, dicho documental pertenece al modo expositivo, pues su texto se dirige al espectador directamente, con intertítulos o voces que presentan una argumentación sobre el mundo histórico. Las imágenes sirven como ilustración o contrapunto. En un texto al servicio de la persuasión, este modo expositivo enfatiza la impresión de objetividad y de juicio bien establecido. La exposición incorpora entrevistas, pero estas se subordinan a una argumentación ofrecida por la propia película.

\section{Desde la rurbanidad, un género de la comunicación para el desarrollo}

Nuestra discusión conceptual y las evidencias asociadas muestran de forma incipiente que la historia, la estéti- 
ca y la política del documental hacen de este género diverso de la comunicación audiovisual un modo de representación compatible con la comunicación para el desarrollo.

Dada su rica historia, sus diversas modalidades y su relación indicativa con el mundo real, el documental constituye un dispositivo apto para expandir, entre otras condiciones, las estrategias de intervención o la "caja de herramientas" de los comunicadores interesados en el desarrollo desde un sentido amplio que, mientras trasciende la dimensión económica, focaliza el cambio significativo de las condiciones sociales, políticas, culturales $\mathrm{y}$ ambientales de la vida humana.

En este sentido, en su tratamiento de la rurbanidad, los tres documentales analizados se posicionan desde el compromiso estético con la marginalidad social (Caballos en la ciudad), o ilustran con referencias locales un concepto de la teoría social (Rurbanos), o argumentan sobre la legitimidad pública de una política social (Río Cuarto, ciudad oculta). Sus abordajes privilegian un modo entre expositivo y/o de observación, aptos para interpelar a la sensibilidad de públicos diversos. Sus condiciones de producción, circulación y recepción difieren, por cuanto corresponden a los circuitos del cine profesional, la formación de comunicadores en la universidad pública y la legitimación de la política pública de nivel local. Uno de los aportes significativos de estos documentales, en particular de los citados en primer y segundo término, radica en la deconstrucción de algunos estereotipos conservadores - $\mathrm{a}$ veces reproducidos por otros medios de comunicación- sobre los actores, las experiencias y los contextos del extendido uso de carros con caballos en ciudades de condición muy diversa.

Más allá de estas diferencias y afinidades, todos estos registros audiovisuales despliegan, en su complejo y diverso dispositivo comunicacional, una mirada sensible sobre ciertas problemáticas del desarrollo latinoamericano. En consecuencia, los documentales sobre la condición rurbana, aquí analizados, constituyen relatos que expresan algunos de los alcances y límites de la comunicación para el desarrollo, ese territorio de investigación e intervención con una extensa trayectoria intelectual y política en el subcontinente.

Estos documentales convergen con una teoría del desarrollo que orienta la agenda pública hacia la situación difícil de una vasta y heterogénea masa de trabajadores y ciudadanos empobrecidos, al tiempo que estimula la investigación detallada sobre cómo los excluidos, por ejemplo, los carreros urbanos y sus grupos domésticos, hacen su vida enfrentándose con su condición social vulnerable. Asimismo, dicha teoría, en ocasiones, también sustenta la agencia de las políticas públicas y otras iniciativas sociales específicas a la exclusión como fenómeno estructural de las naciones latinoamericanas. 
Por otra parte, los audiovisuales sobre los carreros coinciden con una comunicación para el desarrollo que, más allá de sus múltiples orientaciones, representa una perspectiva general para designar a una modalidad intelectual comprometida en mejorar la situación vital de la gente que, en este caso a través del uso de carros tirados por caballos, enfrenta en las ciudades latinoamericanas las condiciones económicas, sociales y políticas de una significativa exclusión que siempre interpela a la democracia y la ciudadanía plenas.

\section{Referencias}

Baigorria, O. (1998). En pampa y la vía. Crotos, linyeras y otros trashumantes. Buenos Aires: Perfil.

Barnouw, E. (2005). El documental. Historia y estilo. Barcelona: Gedisa.

Capiello, V. (2009). La ruralización de la ciudad en la prensa digital. Su tratamiento noticioso en diarios digitales argentinos. En G. Cimadevilla \& E. Carniglia (Coord.), Relatos sobre la rurbanidad (pp. 247-266). Río Cuarto: UNRC.

Carlosena, M. (2010). Políticas públicas locales vinculadas a las prácticas rurbanas. En E. Carniglia \& A. Brandolín, Las ciencias sociales en el interior, el interior de las ciencias sociales (pp. 113-132). Río Cuarto: UNRC-FCH.
Carniglia, E. (2012). De labradores y campos de papel. Recepción de prensa agraria por agricultores familiares. Saarbrücken: Editorial Académica Española.

Cimadevilla, G., \& Carniglia, E. (2009). Relatos sobre la rurbanidad. Río Cuarto: UNRC.

Czuri, P. (2004). Géneros fotográficos y sus usos múltiples: la creación e interpretación del mensaje fotográfico. Buenos Aires: Programa Curso de Postgrado IDES/CAS.

Demarchi, P. (2009). La actividad rurbana en la prensa local. En G. Cimadevilla \& E. Carniglia (Coord.), Relatos sobre la rurbanidad (pp. 195210). Río Cuarto: UNRC.

Galimberti, S. (2008). Más que carros y caballos. Rurbanidad, objetos y significados. Trabajo final de licenciatura. Río Cuarto: DCC-FCH-UNRC.

González, L., \& Segretín, S. (2007). Rurbanos. Trabajo final de licenciatura. Río Cuarto: DCC-FCH-UNRC.

Kenbel, C. (2006). A mitad de camino entre lo rural y lo urbano: actores y actividades de rebusque. Trabajo final de licenciatura. Río Cuarto: DCCUNRC.

Lusnich, A. (2007). El drama social-folclórico. El universo rural en el cine argentino. Buenos Aires: Biblos.

Marrone, I., \& Moyano, M. (2001). Imaginarios contrapuestos en la filmografía del agro pampeano argentino. Mundo Agrario. Revista de Estu- 
dios Rurales, 3. Recuperado de http// www.mundoagrario.com.ar

Monteiro, R. (2009). Los que hacen las noticias en la TV local. La construcción de las "actividades de refugio". En G. Cimadevilla \& E. Carniglia (Coords.), Relatos sobre la rurbanidad (pp. 217-230). Río Cuarto: UNRC.

Nichols, B. (1997). La representación de la realidad. Cuestiones y conceptos sobre el documental. Barcelona: Paidós.

Prelorán, J. (2007). El cine etnobiográfico. Buenos Aires: Universidad del Cine, Catálogos.

Rangil, V. (2007). El cine argentino de hoy: entre el arte y la política. Buenos Aires: Biblos.

Rival, S. (2007). Revisiones. En J. Sartora \& S. Rival, Imágenes de lo real. La representación de lo político en el documental argentino (pp. 9-20). Buenos Aires: Libraria.
Schamber, P. (2008). De los desechos a las mercancías. Una etnografía de los cartoneros. Buenos Aires: SB.

Schamber, P., \& Suárez, F. (2007). Recicloscopio. Miradas sobre recuperadores urbanos de residuos de América Latina. Buenos Aires: UNGS, UNLA, Prometeo.

Shammah, C. (2009). El circuito informal de los residuos: los basurales a cielo abierto. Buenos Aires: Espacio Editora.

Williams, R. (2001). El campo y la ciudad. Buenos Aires: Paidós.

\section{Documentales analizados}

Caballos en la ciudad. A. Gershenson, 2004, Argentina.

Ciudad oculta. Municipalidad de Río Cuarto, 2007, Argentina.

Rurbanos. L. González \& M. Segretín, 2007, Argentina. 